\title{
HUBUNGAN PERSEPSI IKLIM KESELAMATAN DENGAN KEPATUHAN PEKERJA KONSTRUKSI PADA PROGRAM K3 DI PROYEK X
}

\author{
Aldian Noor Qolbi*, Partha Muliawan \\ Alamat: Program Studi Kesehatan Masyarakat Fakultas Kedokteran Universitas Udayana \\ *Email: young.qolbi@gmail.com
}

\begin{abstract}
ABSTRAK
Pekerja konstruksi bangunan merupakan pekerjaan padat karya yang sangat berisiko terhadap kesehatan dan keselamatannya. Kepatuhan pekerja pada program K3 di proyek merupakan salah satu perilaku keselamatan yang berhubungan langsung dengan kecelakaan kerja. Salah satu faktor yang dapat mempengaruhi kepatuhan adalah persepsi pekerja terhadap iklim keselamatan. Tujuan penelitian ini untuk menganalisis hubungan persepsi iklim keselamatan terhadap kepatuhan pekerja pada program K3 di proyek X. Penelitian analitik dengan pendekatan kuantitatif menggunakan rancangan cross-sectional. Responden pada penelitian ini berjumlah 108 orang yang dipilih dengan metode systematic random sampling. Hasil menunjukan proporsi responden patuh pada program K3 sebesar 54,63\%. Terdapat hubungan bermakna antara persepsi prioritas dan keberterimaan risiko $(\mathrm{p}=0,015)$ serta persepsi komunikasi dan kepercayaan dalam pelaksanaan $(\mathrm{p}=0,030)$ dengan kepatuhan pada program K3. Selain itu, responden yang memiliki persepsi baik terhadap prioritas dan keberterimaan risiko berpotensi 4,7 kali lebih patuh terdapat program K3 dibanding responden yang memiliki persepsi cukup. Sebagai upaya meningkatkan kepatuhan, pekerja diharapkan lebih peduli terhadap risiko yang dihadapinya di tempat kerja.
\end{abstract}

Kata kunci: pekerja konstruksi, kepatuhan, persepsi iklim keselamatan

ABSTRACT

The construction activities had a high risk of work accident. The workers compliance with OHS program is directly related to work accident on the construction project. One of the factors that related with the workers compliance is the perception of safety climate. The aim of this study is to analyze the correlation between the perception of safety climate to the construction workers compliance with OHS program. This analytic study designed by cross sectional method. The number of the respondents was 108 selected based on systematic random sampling. The result of this study showed that the proportion of the workers compliance with OHS program was $54,63 \%$. The study also showed that variable workers safety priority and risk non-acceptance $(p=0,015)$ and variable safety communication and trust in safety competence $(p=0,030)$ positively correlated with the workers compliance. Furthermore, respondents who had a good perception of workers safety priority and risk non-acceptance potentially 4,7 times to be compliant with OHS program compared with the respondents who had enough perception. To improve compliance, the workers should be more aware of the risk on the worksite.

Key words: The construction workers, the compliance, the perception of safety climate

\section{PENDAHULUAN}

Kegiatan konstruksi bangunan merupakan kegiatan yang memiliki risiko kecelakaan yang tinggi. Terlebih lagi pada kegiatan konstruksi bangunan yang merupakan salah satu pekerjaan padat karya karena dalam pekerjaannya kebanyakan dilakukan secara manual oleh pekerja. Sehingga pekerja konstruksi bangunan sangat berisiko terkena bahaya yang dapat membahayakan kesehatan dan keselamatannya selama mereka bekerja. Kegiatan konstruksi bangunan menempati urutan utama pekerjaan yang paling berbahaya. Hal ini dikarenakan kegiatan konstruksi memiliki risiko kecelakaan kerja fatal 5 kali lebih tinggi dan risiko cedera utama 2,5 kali lebih tinggi dibandingkan 
sektor manufaktur (Yahya, dkk., 2014). Di Indonesia, angka kecelakaan kerja sebesar $32 \%$ terjadi di sektor konstruksi dan manufaktur, $9 \%$ sektor transportasi, $4 \%$ sektor kehutanan, pertambangan 2\% dan sisanya dari sektor lain (Aminah, 2015).

Umumnya kejadian kecelakaan kerja di konstruksi bangunan cenderung diakibatkan oleh unsafe act dari pekerja itu sendiri. Handayani (2014) melalui penelitian di proyek konstruksi menyebutkan, 88\% kecelakaan oleh perilaku pekerja, 10\% akibat dari lingkungan dan $2 \%$ disebabkan faktor lainnya. Salah satu perilaku buruk pekerja yang dapat meningkatkan risiko kecelakaan adalah tidak patuh terhadap program K3 yang diterapkan di tempat kerjanya. Seperti halnya yang disebutkan oleh Aprilliawan \& Widowati (2016) bahwa pekerja yang tidak patuh menggunakan APD seperti sarung tangan 6,14 kali berisiko mengalami kecelakaan kerja dibandingkan yang patuh menggunakan sarung tangan saat bekerja di perusahaan parquet Temanggung.

Salah satu faktor yang dapat mempengaruhi kepatuhan pekerja terhadap program K3 di tempat kerja adalah iklim keselamatan. Iklim keselamatan merupakan persepsi atas kebijakan, prosedur dan praktik atas keselamatan di tempat kerja. Keberadaannya di tempat kerja dapat mempengaruhi $7,8 \%$ kepatuhan pekerja pada peraturan di tempat kerja (Prihatiningsih \& Sugiyanto, 2010). Instrumen yang dapat digunakan dalam mengukur persepsi iklim keselamatan ini adalah Nordic Occupational Safety Climate Questionnaire (NOSACQ-50). Kuesioner ini memiliki tujuh variabel dalam mengukur persepsi iklim keselamatan yaitu manajemen prioritas, komitmen dan kompetensi keselamatan; manajemen pemberdayaan keselamatan; dan manajemen kesetaraan keselamatan yang termasuk dalam persepsi iklim keselamatan manajemen. Sedangkan pada persepsi iklim keselamatan pekerja yaitu komitmen keselamatan pekerja; prioritas dan keberterimaan risiko keselamatan; komunikasi dalam pelaksanaan keselamatan dan kepercayaan sesama rekan kerja dalam kompentensi keselamatan; serta tingkat kepercayaan pada efektivitas sistem keselamatan (Kines, dkk., 2011).

\section{METODE PENELITIAN}

Penelitian ini merupakan penelitian analitik dengan pendekatan kuantitatif. Rancangan penelitian menggunakan metode cross-sectional untuk menganalisis persepsi iklim keselamatan manajemen dan keselamatan pekerja serta hubungannya dengan kepatuhan pekerja konstruksi pada program K3 di proyek X. Populasi terjangkau pada penelitian ini adalah seluruh pekerja konstruksi diluar karyawan kantor yang bekerja di proyek X. Jumlah sampel minimum pada penelitian ini 108 responden. Teknik pengambilan sampel menggunakan teknik systematic random sampling.

Instrumen yang digunakan pada penelitian ini adalah kuesioner untuk mengukur kepatuhan responden pada program K3 sebagai variabel tergantung dan Nordic Occupational Safety Climate Questionnaire untuk mengukur determinan persepsi iklim keselamatan sebagai variabel bebas. Selain itu juga, peneliti menggambarkan karakteristik responden yaitu usia, jenis kelamin, status perkawinan, pendidikan dan masa kerja menggunakan 
kuesioner. Seluruh kuesioner yang tahun (35,19\%). Keseluruhan (100\%) digunakan tersebut telah diuji validitas dan responden berjenis kelamin laki-laki. realibilitasnya. Pengambilan data dilakukan menggunakan metode wawancara dengan Ditinjau dari status pernikahannya, 29,63\% responden belum menikah, 69,44\% sudah memberikan lembar persetujuan kepada menikah dan cerai sebanyak 0,93\%. responden terlebih dahulu. Analisis Mayoritas tingkat pendidikan responden kuantitatif data menggunakan tiga analisis data yaitu univariabel, bivariabel dengan uji chi-square dan multivariabel dengan uji multiple logistic regression. Penelitian ini telah diperiksa sesuai ethical clearance dari Komisi Etik Penelitian Litbang FK Unud/RSUP Sanglah dengan nomor 2019.01.1.0512 tertanggal 18 April 2019.

\section{HASIL} lulusan SMA/sederajat (62,96\%). Responden yang bekerja 4-6 bulan merupakan proporsi yang paling banyak (43,52\%). Selain itu, diketahui bahwa dari 108 responden terdapat $54,63 \%$ yang patuh pada program K3. Pada Tabel 2 menunjukkan gambaran kepatuhan pekerja memilki perbedaan yang tidak terlalu signifikan. Proporsi pekerja patuh lebih besar yaitu 54,63\%.

Berdasarkan Tabel 1, ditemukan bahwa umur responden pada penelitian ini paling banyak berada pada umur 30-39

Tabel 1. Gambaran Karakteristik Responden

\begin{tabular}{|c|c|c|}
\hline Karakteristik Responden & Frekuensi (n) & Proporsi (\%) \\
\hline \multicolumn{3}{|l|}{ Umur } \\
\hline 20-29 Tahun & 32 & 29,63 \\
\hline 30-39 Tahun & 38 & 35,19 \\
\hline 40-49 Tahun & 25 & 23,15 \\
\hline$\geq 50$ Tahun & 13 & 12,04 \\
\hline \multicolumn{3}{|l|}{ Jenis Kelamin } \\
\hline Laki-laki & 108 & 100 \\
\hline Perempuan & 0 & 0 \\
\hline \multicolumn{3}{|l|}{ Status Pernikahan } \\
\hline Belum Menikah & 32 & 29,63 \\
\hline Sudah Menikah & 75 & 69,44 \\
\hline Cerai & 1 & 0,93 \\
\hline \multicolumn{3}{|l|}{ Pendidikan } \\
\hline Tidak Sekolah & 6 & 5,56 \\
\hline SD/Sederajat & 9 & 8,33 \\
\hline SMP/Sederajat & 25 & 23,15 \\
\hline SMA/Sederajat & 68 & 62,96 \\
\hline \multicolumn{3}{|l|}{ Lama Kerja } \\
\hline 1-3 Bulan & 24 & 22,22 \\
\hline 4-6 Bulan & 47 & 43,52 \\
\hline$\geq 7$ Bulan & 37 & 34,26 \\
\hline
\end{tabular}


Tabel 2. Gambaran Kepatuhan Responden

\begin{tabular}{lccc}
\hline & Kategori & Frekuensi (n) & Proporsi (\%) \\
\hline Patuh & 59 & 54,63 \\
Tidak Patuh & 49 & 45,37 \\
\hline
\end{tabular}

Tabel 3. Hubungan Persepsi Iklim Keselamatan dengan Kepatuhan

\begin{tabular}{|c|c|c|c|c|c|c|}
\hline \multirow{2}{*}{$\begin{array}{l}\text { Persepsi Iklim } \\
\text { Keselamatan }\end{array}$} & \multirow[b]{2}{*}{$\begin{array}{l}\text { Patuh } \\
(\mathrm{n}=59)\end{array}$} & \multirow[b]{2}{*}{$\begin{array}{l}\text { Tidak Patuh } \\
(\mathrm{n}=49)\end{array}$} & \multicolumn{4}{|c|}{ Kepatuhan Responden $(\mathrm{n}=108)$} \\
\hline & & & Total & PR & $95 \%$ CI & $\mathbf{p}$ \\
\hline $\begin{array}{l}\text { Manajemen prioritas, } \\
\text { komitmen dan } \\
\text { kompetensi } \\
\text { keselamatan }\end{array}$ & & & & 0,90 & $0,69-1,18$ & 0,467 \\
\hline Baik & $37(52,11 \%)$ & $34(47,89 \%)$ & $71(100 \%)$ & & & \\
\hline Cukup & $22(59,46 \%)$ & $15(40,54 \%)$ & $37(100 \%)$ & & & \\
\hline $\begin{array}{l}\text { Manajemen } \\
\text { pemberdayaan }\end{array}$ & & & & 1,52 & $0,84-2,75$ & 0,154 \\
\hline keselamatan & & & & & & \\
\hline Baik & $22(64,71 \%)$ & $12(35,29 \%)$ & $34(100 \%)$ & & & \\
\hline Cukup & $37(50 \%)$ & $37(50 \%)$ & $74(100 \%)$ & & & \\
\hline $\begin{array}{l}\text { Manajemen } \\
\text { kesetaraan }\end{array}$ & & & & 0,89 & $0,63-1,24$ & 0,489 \\
\hline keselamatan & $31(54,63 \%)$ & $29(45,37 \%)$ & $60(100 \%)$ & & & \\
\hline $\begin{array}{l}\text { Baik } \\
\text { Cukup }\end{array}$ & $28(58,33 \%)$ & $20(41,67 \%)$ & $48(100 \%)$ & & & \\
\hline $\begin{array}{l}\text { Komitmen } \\
\text { keselamatan pekerja }\end{array}$ & & & & 1,18 & $0,88-1,60$ & 0,254 \\
\hline $\begin{array}{l}\text { Baik } \\
\text { Cukup }\end{array}$ & $\begin{array}{l}28(41,18 \%) \\
21(52,50 \%)\end{array}$ & $\begin{array}{l}40(58,82 \%) \\
19(47,50 \%)\end{array}$ & $\begin{array}{l}68(100 \%) \\
40(100 \%)\end{array}$ & & & \\
\hline $\begin{array}{l}\text { Prioritas dan } \\
\text { keberterimaan risiko } \\
\text { keselamatan }\end{array}$ & & & & 2,55 & $0,93-6,99$ & 0,015 \\
\hline $\begin{array}{l}\text { Baik } \\
\text { Cukup }\end{array}$ & $\begin{array}{l}39(41,05 \%) \\
10(76,92 \%)\end{array}$ & $\begin{array}{c}56(58,95 \%) \\
3(23,08 \%)\end{array}$ & $\begin{array}{l}95(100 \%) \\
13(100 \%)\end{array}$ & & & \\
\hline $\begin{array}{l}\text { Komunikasi dan } \\
\text { kepercayaan dalam } \\
\text { pelaksanaan }\end{array}$ & & & & 1,51 & $1,01-2,24$ & 0,030 \\
\hline Baik & $25(58,14 \%)$ & $18(41,86 \%)$ & $43(100 \%)$ & & & \\
\hline Cukup & $24(36,92 \%)$ & $41(63,08 \%)$ & $65(100 \%)$ & & & \\
\hline $\begin{array}{l}\text { Tingkat kepercayaan } \\
\text { pada efektivitas } \\
\text { sistem keselamatan }\end{array}$ & & & & 0,99 & $0,75-1,30$ & 0,922 \\
\hline Baik & $32(45,71 \%)$ & $38(54,29 \%)$ & $70(100 \%)$ & & & \\
\hline Cukup & $17(44,74 \%)$ & $21(55,26 \%)$ & $38(100 \%)$ & & & \\
\hline
\end{tabular}


Berdasarkan analisis bivariabel ditemukan bahwa, hanya dua variabel persepsi iklim keselamatan yang memiliki hubungan bermakna dengan kepatuhan responden pada program K3 yaitu persepsi prioritas dan keberterimaan risiko $(p=0,015)$ serta persepsi komunikasi dan kepercayaan dalam pelaksanaan $(p=0,030)$. Sedangkan variabel persepsi lainnya yaitu manajemen prioritas, komitmen dan kompetensi keselamatan, manajemen pemberdayaan keselamatan, manajemen kesetaraan keselamatan, komitmen keselamatan pekerja dan tingkat kepercayaan pada efektivitas sistem tidak memiliki hubungan yang bermakna dengan kepatuhan responden pada program $K 3(p \geq 0,05)$.

Tabel 4. Analisis Multivariabel Persepsi Iklim Keselamatan dengan Kepatuhan

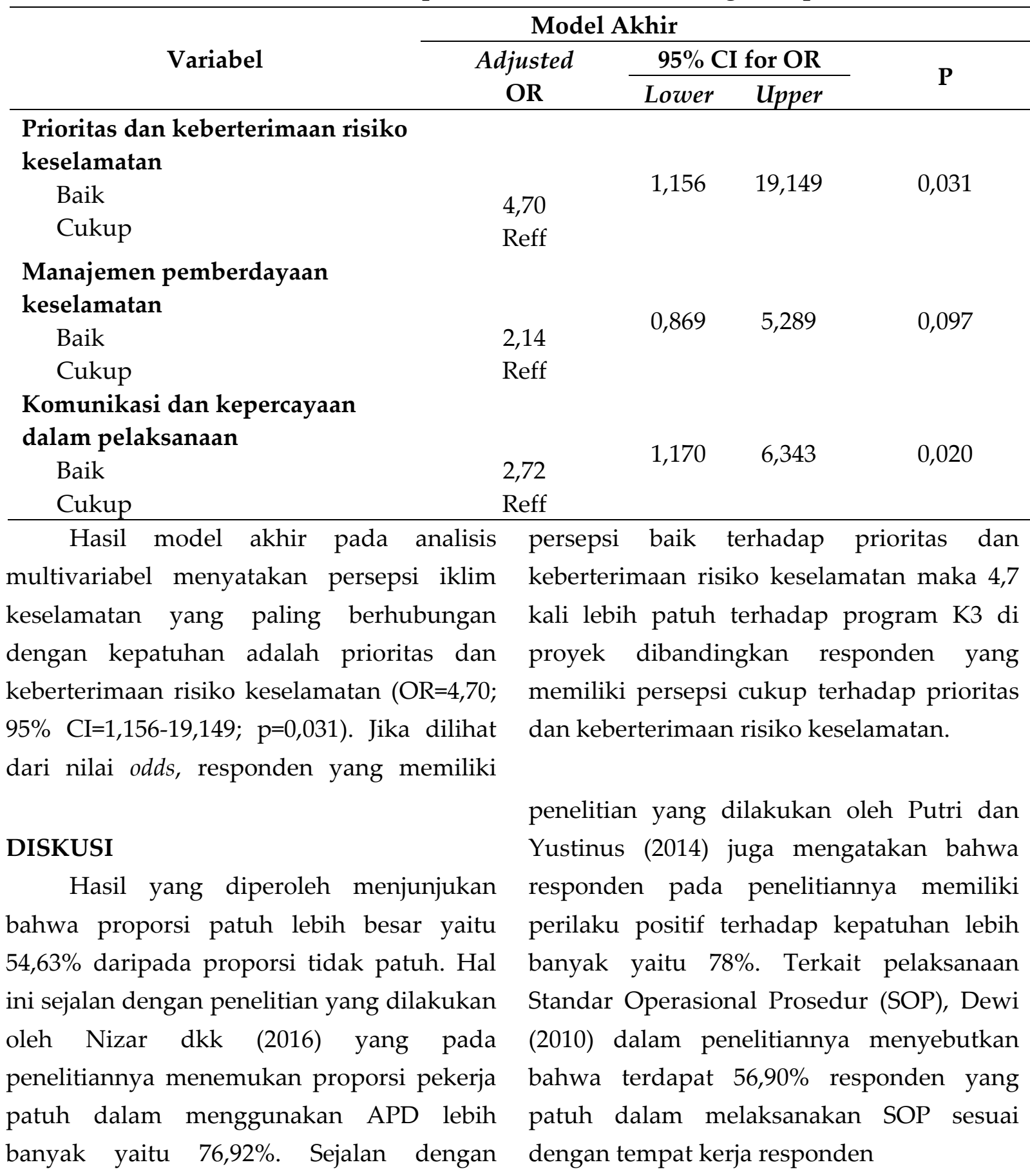


Beda halnya dengan penelitian yang dilakukan oleh Astiningsih dkk (2018) yang pada penelitiannya menyebutkan hanya $46 \%$ responden yang patuh menggunakan APD dan lainnya tidak patuh. Begitu juga penelitian yang dilakukan oleh Nurvita (2015) yang menyebutkan bahwa hanya $21,30 \%$ responden yang patuh melaporkan bahaya di tempat kerjanya.

Perbedaan hasil ini bisa saja didasari terjadinya keberagaman data terkait karakteristik setiap responden maupun keadaan lingkungan di tempat responden bekerja. Kepatuhan seseorang sangat dipengaruhi oleh lingkungan dan individu yang bersangkutan. Perpaduan antara faktor internal dan eksternal dapat mempengaruhi perilaku seseorang terhadap kepatuhan pada program keselamatan di tempat kerjanya (Notoatmodjo, 2012). Sehingga faktor internal dan eksternal pada pekerja juga dapat mempengaruhi kesuksesan dalam pelaksanaan program keselamatan di tempat kerja (Geller, 2001).

Ditemukan bahwa variabel persepsi iklim keselamatan yaitu manajemen prioritas, komitmen dan kompetensi keselamatan $\quad(p=0,467), \quad$ manajemen pemberdayaan keselamatan $(p=0,154)$ dan manajemen kesetaraan keselamatan $(p=0,489)$ tidak memiliki hubungan yang bermakna dengan kepatuhan pekerja pada program K3. Hal ini berbeda dengan pendapat yang dikemukakan oleh Dejoy, dkk (2004) yang menyebutkan bahwa dukungan manajemen merupakan salah satu kontribusi terkuat dalam membangun kinerja pekerja seperti halnya kepatuhan. Begitu juga dengan hasil yang ditemukan oleh Afifah dan Hadi (2018) yang menyebutkan bahwa determinan manajemen prioritas, komitmen dan kompetensi keselamatan $(p=0,001)$ memiliki hubungan bermakna dengan kematangan budaya K3. Berdasarkan nilai odds, responden dengan persepsi baik mengenai manajemen prioritas, komitmen dan kompetensi keselamatan memiliki potensi 6,29 kali lebih tinggi dalam membentuk budaya K3 yang matang dibandingkan dengan responden yang persepsinya kurang baik. Salah satu budaya K3 yang dimaksud adalah patuh terhadap peraturan keselamatan (Afifah \& Hadi, 2018). Perbedaan hasil ini dapat disebabkan oleh karakteristik pekerjaan responden dan perhatian manajemen terhadap pekerja terkait keselamatan yang dapat mempengaruhi persepsi dan kepatuhan pekerja terhadap program $\mathrm{K} 3$ di tempat kerja. Selain itu, kolaborasi antara pekerja dan manajemen juga dapat mempengaruhi kualitas dari perilaku keselamatan di tempat kerja. Choudhry, dkk (2009) menyatakan bahwa upaya manajemen dalam meningkatkan kualitas perlu melibatkan pekerja terutama dalam kegiatan terkait keselamatan.

Persepsi komitmen keselamatan pekerja tidak memiliki hubungan bermakna dengan kepatuhan responden pada program K3. Hasil ini sejalan dengan penelitian yang dilakukan oleh Suyono dan Nawawinetu (2013) yang menunjukkan hasil uji statistik pada penelitiannya menyatakan tidak ada hubungan bermakna antara komitmen dengan perilaku keselamatan, walaupun secara proporsi responden sebagian besar memiliki persepsi yang baik terhadap komitmen kerja. Namun, hasil yang berbeda ditunjukan oleh Ashafahany (2017) yaitu komitmen keselamatan $(p=0,002)$ memiliki 
pengaruh signifikan positif terhadap perilaku keselamatan pekerja pada sektor manufaktur. Pekerja yang memiliki komitmen baik dalam pekerjaannya tentu saja akan melakukan hal terbaik dalam meningkatkan kinerjanya terutama dalam kaitan keselamatan.

Persepsi prioritas dan keberterimaan risiko merupakan variabel yang memiliki hubungan bermakna $(p=0,015)$ dengan kepatuhan pada program K3. Hasil yang sama ditujukkan oleh Puspita dkk (2015) dan Ristia (2017) yang dalam penelitiannya menyatakan bahwa persepsi risiko kecelakaan memiliki hubungan bermakna dengan kepatuhan pekerja dalam menggunakan APD. Hal ini menunjukkan semakin tinggi kesadaran pekerja akan risiko kecelakaan yang akan ditemukannya maka semakin tinggi pula tingkat kepatuhannya pada program K3 di tempat kerja.

Persepsi komunikasi dan kepercayaan dalam pelaksanaan juga merupakan variabel yang memiliki hubungan bermakna dengan kepatuhan pada program K3 ( $\mathrm{p}=0,030)$. Hasil ini sejalan dengan penelitian Ashafahany (2017) yang dalam penelitiannya menyebutkan, variabel komunikasi pekerja memiliki pengaruh positif dengan perilaku keselamatan seperti kepatuhan $(p=0,000)$. Hal ini menunjukan bahwa semakin baik komunikasi yang berjalan pada pekerja maka semakin baik pula kepatuhan pekerja tersebut pada program K3. Pekerja yang memiliki interaksi keselamatan yang baik dengan pekerja lainnya akan memiliki persepsi keselamatan lebih baik sehingga dapat melakukan pekerjaannya dengan lebih aman (Inouye, 2014).
Variabel terakhir yaitu tingkat kepercayaan pada efektivitas sistem keselamatan. Variabel ini tidak memiliki hubungan yang bermakna dengan kepatuhan pekerja pada program K3 dikarenakan nilai $p=0,922$. Walapun variabel ini memiliki skor rata-rata cukup tinggi namun keadaanya tidak memiliki pengaruh dengan kepatuhan pekerja pada program K3 di proyek. Hal ini bisa saja disebabkan karena pengambilan data penelitian yang dilakukan pada tahap akhir proyek sehingga program K3 seperti inspeksi lapangan dan morning briefing sudah tidak berjalan dengan baik dan efektif.

$$
\text { Berdasarkan hasil analisis }
$$
multivariabel, didapatkan hasil akhir bahwa terdapat hubungan bersama-sama antara variabel prioritas dan keberterimaan risiko keselamatan, komunikasi dan kepercayaan dalam pelaksanaan dan manajemen pemberdayaan keselamatan dengan kepatuhan pada program K3.

Pada variabel prioritas dan keberterimaan risiko keselamatan ditemukan bahwa responden yang memiliki persepsi baik terhadap prioritas dan keberterimaan risiko keselamatan berpotensi 4,7 kali lebih patuh pada program K3 dibandingkan responden yang memiliki persepsi cukup terhadap prioritas dan keberterimaan risiko keselamatan $(\mathrm{OR}=4,70$; 95\% CI=1,156-19,149; $\quad \mathrm{p}=0,031)$. Hasil penelitian ini sejalan dengan yang dinyatakan oleh Ristia (2017) yang dalam penelitiannya menyebutkan, berdasarkan analisis keeratan variabel persepsi risiko dengan kepatuhan menggunakan APD bahwa responden yang memiliki persepsi risiko kurang baik mempunya peluang 4,25 kali untuk kurang patuh dalam 
menggunakan APD dibandingkan responden yang memiliki persepsi risiko yang baik (OR=4,250; 95\% CI=1,370-13,188). Inouye (2014) juga berpendapat bahwa persepsi risiko yang rendah dapat meningkatkan toleransi risiko menjadi lebih tinggi dan dapat meningkatkan perliaku berisiko di tempat kerja.

$$
\text { Pada }
$$

manajemen

pemberdayaan keselamatan menunjukkan bahwa responden yang memiliki persepsi manajemen pemberdayaan keselamatan yang baik berpotensi 2,14 kali lebih patuh pada program K3 dibandingkan responden yang memiliki persepsi cukup terhadap manajemen pemberdayaan keselamatan (OR=2,14; 95\% CI= 0,869-5,289; p=0,097). Penelitian dari Christina (2012) menyebutkan bahwa upaya pemberdayaan pekerja oleh manajemen memiliki pengaruh positif terhadap kinerja keselamatan pekerja tesebut.

Variabel terakhir yang masuk dalam model akhir analisis multivariabel adalah komunikasi dan kepercayaan dalam pelaksanaan. Pada uji tersebut menyatakan, responden yang memiliki persepsi baik terhadap komunikasi dan kepercayaan dalam pelaksanaan berpotensi 2,72 kali lebih patuh pada program K3 dibandingkan responden yang memiliki persepsi cukup terhadap komunikasi dan kepercayaan dalam pelaksanaan $(\mathrm{OR}=2,72 ; 95 \% \mathrm{CI}=1,170$ $6,343 ; p=0,020)$. Hasil ini didukung oleh penelitian yang dilakukan oleh Suyono dan Nawawinetu (2013) yang menunjukkan, hasil uji statistik variabel komunikasi dengan perilaku K3 menunjukan hubungan yang bermakna dengan nilai koefisien kontingensi (C) sebesar 0,414, artinya tingkat hubungan komunikasi dan perilaku K3 tergolong cukup kuat.

\section{SIMPULAN}

Berdasarkan pemaparan hasil, maka dapat disimpulkan bahwa berdasarkan karakteristik responden, sebagian besar pekerja berumur 30-39 tahun, seluruhnya berjenis kelamin laki-laki, sudah/pernah menikah, bersekolah sampai SMA/sederajat dan bekerja selama 4-6 bulan. Terdapat dua variabel persepsi iklim keselamatan yang memiliki hubungan bermakna dengan kepatuhan yaitu prioritas dan kebeterimaan risiko $(p=0,015)$ dan komunikasi dan kepercayaan dalam pelaksanaan $(p=0,030)$. Selain itu, prioritas dan keberterimaan risiko merupakan determinan persepsi iklim keselamatan yang paling berpengaruh terhadap kepatuhan pekerja pada program $\mathrm{K} 3(\mathrm{OR}=4,70)$.

\section{SARAN}

Disarankan kepada peneliti selanjutnya untuk melakukan penelitian yang dimulai dari awal proyek hingga tahap akhir untuk mendapatkan hasi persepsi iklim keselamatan lebih baik. Kepada responden diharapkan mulai aktif dalam menjalin hubungan dengan rekan kerja lainnya khususnya dalam meningkatkan upaya-upaya keselamatan di tempat kerja. Sedangkan kepada manajemen, diharapkan menyediakan media komunikasi efektif bagi pekerja dengan rekan kerjanya ataupun pekerja dengan pihak manajemen sehingga hal tersebut dalam meningkatkan hubungan kedua pihak tersebut. 
DAFTAR PUSTAKA

Afifah, A.N., dan Hadi, S. (2018). Analisis Budaya K3 dengan Nordic Occupational Safety Climate Questionnaire dan Safety Culture Maturity Model. Jurnal Fakultas Kesehatan Masyarakat 12(2) ISSN: 19780575; 113-119.

Aminah, A.N. (2015). Kecelakaan Kerja di Indonesia Terbanyak di Sektor Konstruksi dan Manufaktur. Terdapat pada https://www.republika.co.id/berita/nas ional/umum/15/12/11/nz66ig384-

kecelakaan-kerja-di-indonesiaterbanyak-di-sektor-konstruksi-danmanufaktur. Diakses tanggal 29 Januari 2019.

Aprilliawan, Y.B., dan Widowati, E. (2016). Kepatuhan Penggunaan Sarung Tangan dengan Kecelakaan Kerja di Perusahaan Parquet Temanggung. Unnes Journal of Public Health 5(3): 232239.

Ashafahany, M.Z.W.A. (2017). Kekuatan Komunikasi Sebagai Faktor Penunjang Keselamatan Kerja pada Industri Manufaktur. [Skripsi]. Surakarta: Institut Agama Islam Negeri Surakarta.

Astiningsih, H., Kurniawan, B. dan Suroto. (2018). Hubungan Penerapan Program K3 Terhadap Kepatuhan Penggunaan APD pada Pekerja Konstruksi di Pembangunan Gedung Parkir Bandara Ahmad Yani Semarang. Jurnal Kesehatan Masyarakat Vol. 6(4): 300-308.

Choudhry, R.M., Fang, D. dan Lingard, H. (2009). "Measuring Safety Climate of Construction Company". Terdapat pada https://ascelibrary.org/doi/pdf/10.1061/ \%28ASCE\%29CO.1943-7862.0000063.

Christina, W.Y. (2012). Pengaruh Budaya Keselamatan dan Kesehatan Kerja (K3) terhadap Kinerja Proyek Konstruksi. Jurnal Rekayasa Sipil Vol. 6(1): 83-95.

Dejoy, D.M., Schaffer, B.S., Wilson, M.G., Vandenberg, R.J., dan Butts, M.M. (2004). Creating Safer Workplaces: Assessing the Determinants and Role of Safety Climate. Journal of Safety Research, 35; 81-90.

Dewi, N.P. (2010). Faktor-Faktor yang Berhubungan dengan Kepatuhan Pekerja dalam Melaksanakan Standar Prosedur Kerja (Standar Operasional Procedure/SOP) di PT Suzuki Indomobil Motor Roda 4 Plant Tambun II Bekasi Tahun 2010. [Skripsi]. Jakarta: UIN Syarif Hidayatullah Jakarta.

Geller, E.S. (2001). The Psychology of Safety Handbook. New York: Lewis Publishers.

Handayani, D.I. (2014). Penilaian Risiko Keselamatan Kesehatan Kerja. Jurnal Dinamika Rekayasa 10(2), ISSN 18583075.

Inouye, J. (2014). Risk Perception: Theories, Strategies and Next Steps. New Zealand: Campbell Institue National Safety Council.

Kines, P., Lappalainen, J., Mikkelsen, K.L., Olsen, E., Pousette, A., Tharaldsen, J., Tomasson, K., dan Torner, M. (2011). Nordic Safety Climate Questionnaire (NOSACQ-50): A New Tool for Diagnosing Occupational Safety Climate. International Journal of Industrial Ergonomics 41: 634-646.

Nizar, M.F., Tuna, H. dan Sumaningrum, N.D. (2016). Hubungan Karakterisrik 
Pekerja dengan Kepatuhan dalam Pemakaian Alat Pelindung Diri (APD) pada Petugas Laboraturium Klinik di Rumah Sakit Baptis Kota Kediri. Jurnal Preventia Vol. 1(1): 1-6.

Notoatmodjo, S. (2012). Promosi Kesehatan dan Perilaku Kesehatan (Edisi Revisi). Jakarta: PT. Rineka Cipta.

Nurvita, D. (2015). Faktor-Faktor yang Berhubungan dengan Kepatuhan Pelaporan Bahaya pada Pekerja Teknisi Unit Maintenance di PT Pelita Air Service Area Kerja Pondok Cabe, Tanggerang Selatan. [Skripsi]. Jakarta: Universitas Islam Negeri Syarif Hidayatullah.

Prihatiningsih dan Sugiyanto. (2010). Pengaruh Iklim Keselamatan dan Pengalaman Personal terhadap Kepatuhan pada Peraturan Keselamatan Pekerja Konstruksi. Jurnal Psikologi 37(1): 82-93.

Puspita, L., Jus'at, I. dan Marojahan, R. (2015). Hubungan Persepsi Tentang Risiko Kecelakaan Kerja dan Kepatuhan Penggunaan Alat Pelindung Diri pada Pekerja Proyek North Land Ancol Residence PT Jaya Konstruksi Manggala Pratama Tbk. Forum Ilmiah Vol. 12(2): 123-133.
Ristia, E. (2017). Hubungan Persepsi Tentang Risiko dan Alat Pelindung Diri Serta Toleransi Risiko Pekerja dengan Kepatuhan Penggunaan Alat Pelindung Diri di Proyek Konstruksi Mass Rapid Transit Jakarta Tokyu Wika Joint Operation. [Skripsi]. Jakarta: Universitas Islam Negeri Syarif Hidayatullah.

Suyono, K.Z. dan Nawawinetu, E.D. (2013). Hubungan Antara Faktor Pembentuk Budaya Keselamatan Kerja dengan Safety Behavior di PT DOK dan Perkapalan Surabaya Unit Hull Constraction. The Indonesioan Journal of Occupational Safety and Health Vol.2(1): 67-74.

Yahya, K., Hasan, M.A., dan Ebrahim, H. (2014). Factors Influencing Unsafe Behaviors and Accidents on Construction Sites: A Review. International Journal of Occupational Safety and Ergonomics (JOSE), 20(1); 111-125. 